Volume and Issues Obtainable at Center for Sustainability Research and Consultancy

Journal of Business and Social Review in Emerging Economies

ISSN: 2519-089X (E): 2519-0326

Volume 4: Issue 2 December 2018

Journal homepage: publishing.globalcsrc.org/jbsee

\title{
Comparison of Conflict Management Style Between Malaysian and Thai Employees: A Case Study in Top Glove Corporation
}

\author{
${ }^{1}$ Muhammad Amsal Sahban, ${ }^{2}$ Qaiser Abbas \\ ${ }^{1}$ Department of Management, STIM Lasharan Jaya Makassar, Indonesia. amsalsahban@ @mail.com \\ ${ }^{2}$ Department of Economics, Ghazi University, DG Khan, Pakistan. qabbas@ gudgk.edu.pk
}

\begin{tabular}{l}
\hline ARTICLE DETAILS \\
\hline History \\
Revised format: Nov 2018 \\
Available Online: Dec 2018 \\
\hline
\end{tabular}

\section{Keywords}

Conflict styles, rubber

company, malaysian employees,

thai employees

JEL Classification:

M51, M59

\begin{abstract}
Objective: This study investigated the fundamental beliefs regarding crosscultural differences in conflict styles.

Methodology: The sample consisted of 46 employees from 2 different countries between Malaysia and Thailand. $T$ test analysis was used to investigate the effect of conflict styles on both Malaysia and Thai employees.

Results: Findings revealed that the avoiding and compromising styles are generally the most preferred by both Malaysian and Thai employees; accommodating and collaborating are the next preference, followed by competing. Competing is preferred by Malaysian workers rather than Thai workers. While, Thai employees use more collaborating style rather than Malaysian Employee. We also found that Thai employees rely more on comprising style than Malaysian employees do.

Finally, the meaning of three of the five styles is different from Malaysian and Thai employees: only avoiding and accommodating conflict styles are interpreted similarly by both groups. Therefore, we conclude that both Malaysian and Thai experience higher levels of task conflict as they use more avoiding style in their workplace. Areas for future research are considered to get a further finding of this research.
\end{abstract}

(C) 2018 The authors, under a Creative Commons AttributionNonCommercial 4.0

Corresponding author's email address: amsalsahban@ gmail.com

Recommended citation: Sahban. M.A., Abbas, Q. (2018). The Comparison of Conflict Management Style Between Malaysian and Thai Employees: A Case Study in Top Glove Corporation. Journal of Business and Social Review in Emerging Economies, 4(2)207-220

DOI: 10.26710 /jbsee.v4i2.244

\section{Introduction}

Malaysia and Thailand are trying to embark on a very big project "Rubber City" close to Kedah-Thai border in no distance future.As Malaysia is recognized as the largest rubber gloves producer while Thailand is recognized as the world producer of many internationally branded automobile tires. The cooperation for the development of rubber-related industries in Kedah will help companies in Malaysia and Thailand to get the competitive prices for their rubber and to make an uninterrupted supply of the raw material to these manufacturing supplies. The border area close to Prakob border checkpoint in Thailand, and Kota Putra in Kedah is known as the most comfortable place between these two countries.

When the project is finished, it will lead to increase in the demand for rubber for at least 200,000 tons per year (Thai News Service, 2013). These benefits of cooperation between both countries will lead to job 
opportunities with improved income, good standards of living and well-being of the people. The project will bring high revenue to both countries, mainly in the southern region of Thailand. The Royal Thai Embassy in Singapore shows that Malaysia needs 30,000 workers from southern Thailand.

\subsection{The Problem Statement}

According to Kinney (2001) shows that the emergence of conflict is caused by cross-cultural conflict. It usually happens when one group of people working with other groups that have different cultural identities and beliefs. There is some conflict between each other as the power of culture is strong.It is observed that, these class of people gets very hardto reach a better understanding with each other, and acceptably takes time to get used to each other conflict.

The conflict between immigrant employees among Malaysia and Thailand happens in all managerial levels of socialization in the company. When disagreement happens, the relationship becomes not stronger and indirectly will affect the output, working environment and company's goal in totality. As both countries' governments need the studies of the project between two countries, the study of conflict management in the workplace between employees from Malaysia and Thai will be revealed in this report.

\subsection{Research Questions}

1) Do we have a difference in the statistical significant of preference in the competing style between Malaysian and Thai employees?

2) Do we have a difference in the statistical significant of preference in the collaborating style between Malaysian and Thai employees?

3) Do have a difference in the statistical significant of preference in the compromising style between Malaysian and Thai employees?

4) Do we have a difference in the statistical significant of preference in avoidance of style between Malaysian and Thai employees?

5) Do we have a difference in the statistical significant of preference in the accommodating style between Malaysian and Thai employees?

\subsection{Research Objectives}

This research focuses on the following set objectives, to a achieving its goals, namely:

1) To examine the difference in preference of competing style between Malaysian and Thai employees.

2) To examine the difference in preference of collaborating style between Malaysian and Thai employees.

3) To examine the difference in preference of compromising style between Malaysian and Thai employees.

4) To examine the difference in preference of avoiding style between Malaysian and Thai employees.

5) To examine the difference in preference of accommodating style between Malaysian and Thai employees.

\section{LITERATURE REVIEW}

A term of conflict can be defined as an attempt by people to show their insight to their opposition that may surface because they have different needs, views, beliefs, values or goals. We clearly cannot stay away from conflict that could bring negative or positive influence in organizations (The foundation Coalition).

\subsection{Styles of Managing Conflict}

It is acceptable that professions such as teachers, trainers, mediators, organizational consultants, and human resource managers use conflict style inventories in their work to assist people to see and improve their responses to conflict. Revealing of styles makes people recognize that they have choices to respond to conflict. Since each style has a particular way of interacting with others in disagreement, style awareness also can seriously help people to meet the demands of those they live and work together with. 
According to Hocker and Wilmot (1998), conflict management is a means of planning to avoid conflict where necessary, and organizing to settle theconflict where it is seen as quickly as possible.

Different methods have been followed in studying conflict management. In one popularly used paradigm, a person's conflict management style is seen as representing the degree to which he or she is encouraged by two non-exclusive goals: reaching one's own interest and getting another person's interest (Thomas, 1992). Competing or dominating - promotes one's own interests above the other party's - shows a high self-interest and low other-interest. Collaborating, or negotiating to try to please both parties, shows both high self- and other-interest. Accepting the other party's interests first, shows alow self-interest and high other-interest. Preventing from withdrawing or ignore the disagreement, leads to both low self- and otherinterest. Finally, compromising to give something up in order to get something, shows a middle level of both self- and other-interest. Several current researchers have employed a number of simplified frame works depending on fewer conflict management styles.

As there are differences in these techniques, distinctions among the styles that represent a mix of self- and other-interests. For example, Oetzel and Ting-Toomey (2003) distinguishes conflict management style as dominating, avoiding, or integrating, with the latter presumably encompassing collaborating, compromisingand accommodating. Tinsley (2001) related factors in making a negotiation by reference to apower, interests, or regulations. Morris et al. (1998) centered on the competing and preventing styles.

In line with that, Thomas Kilmann (1974) has begun some major ways of using people use to deal with conflict matters, which are:

1) Preventing; also referred to as LOSE-LOSE process, preventing is known as uncooperative and ignorant behaviors. People try to remain not concerned with these. These methodstend to worsen the conflict over time.

2) Accommodating; that is also known as a LOSE - WIN method. It implies submission to others' ideas. Very often, this method leads to conflict within the individual by ignoring other people's wishes and concerns. This is a dominating style and also known as WIN-LOSE method.

4) Compromising; also referred to as A WIN SOME-LOSE method which involves finding a middle path to settle conflicts. This methodacceptably leaves both parties partially satisfied.

5) Collaborating; also known as strong, assertive and cooperative behavior. A mutual give and take approach is encouraged. Collaborating is a WIN-WIN methodfor settling conflict issues.

\subsection{Nature of conflict}

We clearly cannot prevent the conflict at work as long as you still have any link with people. The majority of us is affected by conflict in some form,or another every day (Syria and Aula, 2010). It is because everybody brings different ideas, goals, values, beliefs and needs to work together,and these differences are the primary strength of teams. These same differences unavoidably lead to conflict, even when the degree of conflict is low.

Some of this disagreement affects us directly, while some we may simply be observed. But all of it affects us in one way or the other, just as it affects the organizations we belong to. Although the type of disagreement, we may notice differences from time to time, but a particular thing remains constant; conflict at work is unavoidable. It is very important for us to know how to manage it well and, perhaps, even come to recognize its possible benefits.

\subsection{Background of Top Glove Company}

The Malaysian rubber company "Top Glove" was established in 1991 and has come a long way from its little beginnings. What took off as a modest business venture of 1 factory, 3 production lines and 100 staff, is now the world's largest rubber glove manufacturer, boasting 25 factories, 466 production lines and capacity estimated to be around 40.7 billion gloves annually. 
It was recorded that on this day, $27^{\text {th }}$ of March, 2001, Top Glove was placed on the second position board of the Malaysia bourse, Bursa Saham Kuala Lumpur, under one year,expanded to the Main Market of the Kuala Lumpur Stock Exchange. It has a shareholder fund of RM1.28 billion or USD409.7 million with an annual turnover of about RM2.31 billion or USD740.6 million as at financial year ended 31 August 2012. It is also one of the component stocks of the FTSE Bursa Malaysia ("FBM") Mid 70 Index, FBM Top 100 Index and FBM Emas Index with a market capitalization of RM3.74 billion as at 20 May 2013. These attainments are in no small part acknowledged to the good leadership quality of Tan Sri Lim Wee Chai and a dedicated board of directors, in parternship with 11,000-strong workforce, havetaken Top Glove into a resounding success in today's' world.

At Top Glove, customers are specially treated with an excellent service from their quality products, efficient, costing and excellent customer service, which continues to be its chief priority. With this vision, the company will continue to intensify investments in $\mathrm{R} \& \mathrm{D}$, IT and automation, towards on-going improvements in product quality and production efficiency. Moving forward, the . In line with its recent land acquisition, the company is also moving upstream by going into rubber plantation with the aim of reducing the instability in the latex cost. Top Glove's remained determined in obtaining $30 \%$ of the global market share by the year 2015. At this junction, the company has started on a quick capacity enlargement and strike a balance in its capacity mix of natural rubber and synthetic rubber gloves. In line with its recent land acquisition, the company is also moving upstream by going into rubber plantation in order to mitigate the volatility in latex cost.

\subsection{Culture and Personality of the Malaysians}

Malaysia is a seen as a verse-racial country, consisting of about 23.27 million people (Census, 2001), with 65.1 percent of indigenous Bumiputras, 26 percent of Chinese, 7.7 percent of Indians and 1.2 percent relating to others. The Malay Archipelago is at the consensus of two dominant nations: China to the east and India to the west. Cultural and religious interaction from the Spice Route time has demonstrated a vibrant culture in this part of Asia. The seafarers from India lead to Buddhism, Islam and Hinduism and the Chinese resulting to Taoism and Confucianism and also archipelago. The colonization of the Portuguse, in the sixteen century, accompanied citizen of Dutch during the eighteenth century, followed by the colonization of the British during the nineteenth century, during this time the Christian religion and western system of Governance was introduced.

Resulting in its attainment for independence from the British in 1957, Malaysia was surrounded by the Japanese for more than three years during the Second World War. Following their independence, mass migration majorly from India and China to Malaysia, through indentured labor and people seeking economic gain, stopped. This comprehensive history gives the backdrop to understanding the cultural importance that affects management style in Malaysia. Therefore, Malaysians are categorized by these defined integrated customs orientation, unity, good understanding among seniors/elderly ones and abiding with rules and regulation of the land and living in harmony with one another (Asma, 1992). Disagreement is seen as deleterious to team spirit and harmony since Malays have traditionally been practiced among communal way of life. Service to the society is performed in unity under Malaysian contex.

\subsection{Culture and Personality of the Thais}

Staying in the heart of Southeast Asia, Thailand is seen as an agricultural country, having a population size of 62 million, with 80 percent of Thai, 10 percent of Chinese, 3 percent of Malay, and while others are minorities consisting of the Mon and Khmer tribes, with a high level of cultural and social unity. Relating to religion, of which 95 percent is Thai people, which are Buddhist, 4 percent are Muslim, and 1 percent represents other religion. They practice a monarchy democratic constitutional political system. Thai is their official language, but English is understood in most of the major cities (Tourism Authority of Thailand, 2007). In line with economic advancement, the integrity of the Thais people is another important factor that brings investors from around the world. To do great exploits in doing business in Thailand, by learning about Thai values is of great paramount. 
Komin (1995) conducted a nation-wide research and discovered that nine prevalent value orientations held by Thai people which make Thais different from other people's collectivistic cultures: "ego orientation" (concept of face-saving), "grateful relationship orientation", "smooth interpersonal relationship orientation", "flexibility and adjustment orientation", "religio-physical orientation" (spiritual beliefs), "education and competence orientation", “interdependence orientation", “fun-pleasure orientation", and "task-achievement orientation". As face and interpersonal relationships are the most importance values of the Thai people. According to the face negotiation theory, Thai people accept conflict styles that keepagreement more than other collectivistic cultures.

In accordance with Ting-Toomey and her companions (e.g. see Oetzel et al., 2000; Ting-Toomey, 1999, 2003), Fieg (1989) obsereved that Thai people finds it very difficult to save face, both for themselves and for others. Thai people value good interpersonal relationships, so they see disagreement as a negative phenomenon that can be prevented.Manifestation of anger, disagreement, and embarrassment of others are some examples of behavior not sanctioned because they cause one, as well as others, to lose face. Whereas in advanced countries such as America, childrenare allowed to think independently and constructively. The Thai children are discouraged from raising up contrasting views or challenging others, mainly teachers and others who are older and highly placed in the society.

\subsection{Thomas-Kilmann Conflict Styles}

Inagreement with Thomas-Kilmann, there are 5 different ways of conflicting, which are: accommodating, avoiding, collaborating, competing and compromising. The explantionsof the five conflict styles are discussed below:

1) Accommodating; this is when you agree to a high-degree, and it may be at your own disadvantage, and actually work against your own aims, objectives, and desired expectation. This method is very efficient when the other party is more experienced or has a better solution. It can also be reliable for keeping future interaction with the other party.

2) Avoiding; this is when we run away from the issue at hand. As a result, we do not help other party reach their aims and objectives, and attaining their goals in life. This is more effective when the issue is insignificance. It is also reliable when the matter at hand is difficult to handle. It is also very effective when the atmosphere is tensed and you need to allow some space to make peace to reign. Sometimes matters do settle themselves, but "hope is not a disaster", and overall, avoidance is not a good long term method.

3) Collaborating; this is where you cooperate or team with the other parties to acquire both of your missions. This is how you solve the "win-lose" paradigm and seek the "win-win." This can be very reliable for complex situations where you need to find a definite solution. This can also mean to restructure the challenge in order to allow a bigger space and room for everybody's opinion. The constraint is that it needs a high-degree of trust and getting an agreement that needs a lot of time and input to get everybody on board and to scrutinize all the various opinions.

4) Competing; this is the "win-lose" technique. You act in a very assertive way to get your goals, without seeking for an agreement with the other party, and it may be at the disadvantage of the other party. This method is suitable for emergencies when time is right, or when you need quick, decisive action, and people are notified and given support for this method.

5) Compromising; this is the "lose-lose" situation where neither party really gets what they stand. This requires a moderate level of assertiveness and support. It may be right for situation where you need an immediate solution, or where both sides have equally reasonable goals. The danger is to allow some of negotiation as a simple way out, when collaborating would result to a better solution.

\section{Methodology}

This part explained the research design used, sampling procedure employed, data collection procedure, and the measurement. In the section of measurements, this section details the entire operational definition of variables and reason behind choosing the instrument. The participants were asked to indicate how often 
they demonstrate the listed by using Thomas Kilman conflict mode instrument. Altogether there are 37 items consist of 30 items from conflict handling skills (competing, collaborating, compromising, avoiding, accommodating), and respondent's personal background 7 items.

\subsection{Research design}

The research design framework comprise of 5 different conflict styleswhch are: competing, collaborating, compromising, avoiding, and accommodating. Examination is carried out to analyze the effect differences of culture regions (Malaysian and Thai) on each disagreement styles of management. Drawn from reviewed literatures, the dependent variable is an important variable, whereby the varianceisaimed at explaining the two independent variables relating to Thai and Malaysian nationality as shown in Figure 3.1 below:

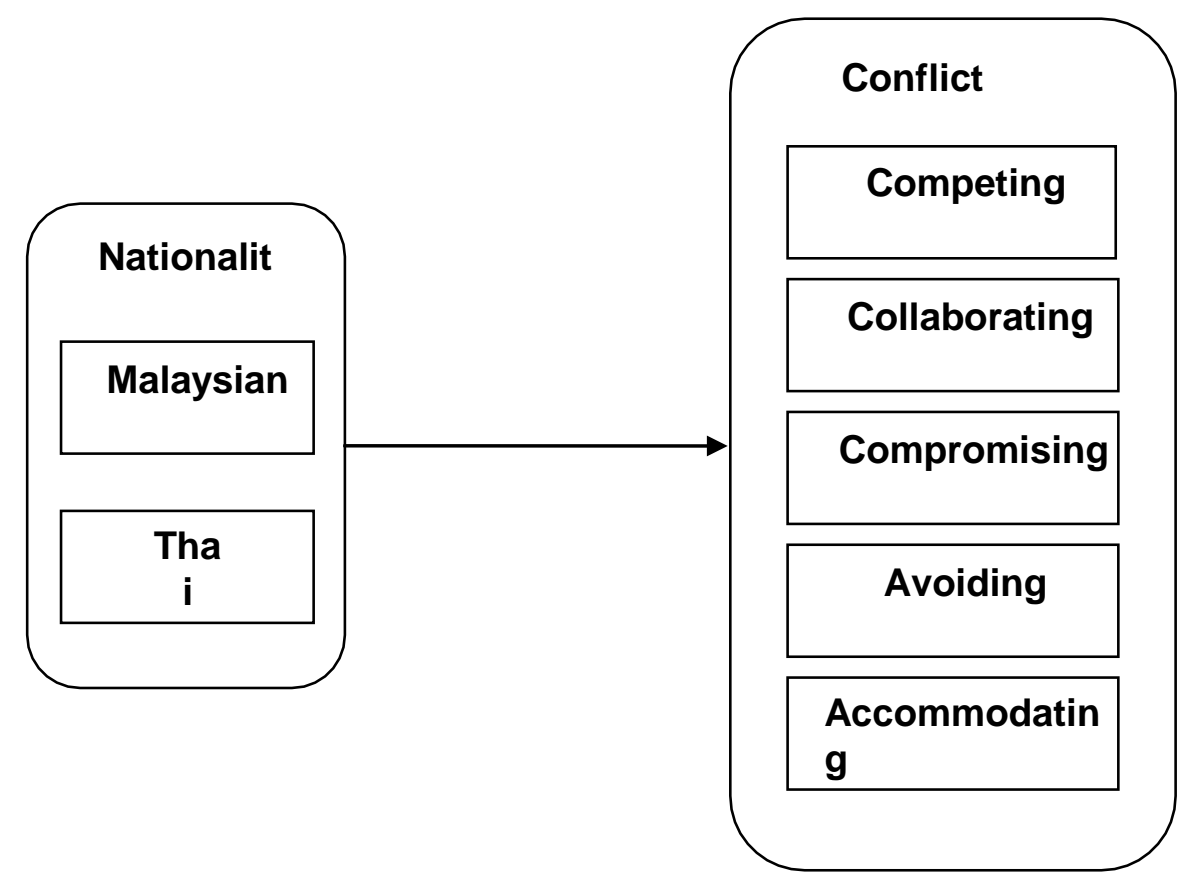

\section{Figure 3.1. Proposed Research Model}

After elaborating the network of research model describing associations among the variables, relevant hypotheses can be developed and tested. In this research, the under listed hypothesis used are:

H1: There is a significant difference in preference for competing conflict style between Malaysian and Thai employees.

$\mathrm{H} 2$ : There is a significant difference in preference for collaborating conflict style between Malaysian and Thai employees.

H3: There is a significant difference in preference for compromising conflict style between Malaysian and Thai employees.

H4: There is a significant difference in preference for avoiding conflict style between Malaysian and Thai employees.

H5: There is a significant difference in preference for accommodating conflict style between Malaysian and Thai employees.

\subsection{Sampling design}

The researcher has used a quantitative method since the research aims and objectives is to find out and compare the conflict styles management among Malaysian and Thai employees. For the population and sample, the population of this research relates to the upper managements, middle managements, junior managements, administrative staffs, and skilled workers who have been working in Top Glove Company. The two factories are located in Sungai Petani, Kedah in Malaysia and Sadao, Songkhla in Thailand were 
chosen selected with the coverage of the research. To choose the sample, suitable sampling was employed because of their suitability and easy reach to the researcher.

The data obtained started on April $4^{\text {th }}, 2013$ to May $3^{\text {rd }}, 2013$. The questionnaire design comprises of 2 sections; demographic information in closed-ended question and conflict styles, explaining related behavioral responses translated in Thai language for Thai employees.

\subsection{Measurement}

The Thomas-Kilmann Conflict Mode Instrument was discovered in 1974 by Kenneth Thomas and Ralph Kilmann. The instrument has 30 statements in which each statement has 2 selections which are " $\mathrm{A}$ " or "B", the respondent selects the choice that best explains the action the respondent like to embark. The "A" or "B" answers correspond to 1 of 5 conflict modes which include; competing, collaborating, compromising, avoiding, and accommodating. When the respondents have finished using the instrument, the scores were added up for each of the five conflict modes. The following table (Table 3.1) explains the Thomas-Kilmann Conflict Mode Instrument scores of low, middle, and high.

\section{Table 3.1 Thomas-Kilmann Conflict Mode Instrument scores of low, middle, and high}

\begin{tabular}{lccc}
\hline Style & Low & Middle & High \\
\hline Competing & $0-3$ & $4-7$ & $9-12$ \\
Collaborating & $0-5$ & $6-8$ & $10-12$ \\
Compromising & $0-4$ & $5-7$ & $11-12$ \\
Avoiding & $0-4$ & $5-6$ & $8-12$ \\
Accommodating & $0-3$ & $4-5$ & $7-12$ \\
\hline
\end{tabular}

\subsection{Analysis}

The analyses of data were completed using SPSS version 16 for windows. A descriptive statistical analyze using frequencies and percentages were used to describe the demographic variables. Research questions were addressed using the independent t-test. The instrument used was on the ratio measurement scale (scoring) and total scores were computed for each category under investigation. All data analysis was performed at the probability of 0.05 of significance levels.

The independent t-test was used with those variables with two subscales to test for difference in proportions in another category. The independent $\mathrm{t}$ - test is one of the two t-test most commonly used for analyzing categorical data (Fraenkel \& Wallen, 2006).

\subsection{Limitations}

Because of these reasons, the issues were randomly selected, generalizations should be limited to the reported findings from this study and cannot be applied to any other group.It can be interpreted that there was no attempt to generalize the findings of the study to the large population of Malaysian and Thai employees.

\section{Findings}

This part is a presentation of the results from the analyses used to address the research questions in this study. The purpose of this study was to examine the difference in preference of conflict styles between Malaysian and Thai employees in Top Glove Company. The instrument developed by Thomas-Kilmann Conflict was developed tocollect data from the respondents. There were a total of 46 employees who participated in the study.

\subsection{Demographic Characteristics}

Demographic statistics were used to address the demographic characteristics of the respondents in this study. The demographic included; gender, age, education, marital status, nationality, working position, 
and years of working experience. The results of the analyses are presented in the Tables 4.1-4.7 that follows.

\subsubsection{Gender of respondents}

Table 4.1 shows the distribution of the number of respondents by sex of the respondents $(n=46), 34$ (73.9\%) were females.

Table 4.1 Frequency and Percentage of Respondents by Gender

\begin{tabular}{|cl|c|c|c|c|}
\hline & & Frequency & Percent & Valid Percent & $\begin{array}{c}\text { Cumulative } \\
\text { Percent }\end{array}$ \\
\hline Valid & Male & 12 & 26.1 & 26.1 & 26.1 \\
& Female & 34 & 73.9 & 73.9 & 100.0 \\
& Total & 46 & 100.0 & 100.0 & \\
\hline
\end{tabular}

\subsubsection{Age of respondents}

Of the respondents $(n=46), 34(73.9 \%)$ were under 24 , and $9(19.6 \%)$ were age $25-34$. Table 4.2 summarizes the results of the age distribution of the participants.

Table 4.2 Frequency and Percentage of Respondents by Age

\begin{tabular}{|cl|c|c|c|c|}
\hline & Frequency & Percent & Valid Percent & $\begin{array}{c}\text { Cumulative } \\
\text { Percent }\end{array}$ \\
\hline Valid & Under 24 & 34 & 73.9 & 73.9 & 73.9 \\
& 9 & 19.6 & 19.6 & 93.5 \\
35 to 34 & 1 & 2.2 & 2.2 & 95.7 \\
Age 45 or older & 2 & 4.3 & 4.3 & 100.0 \\
Total & 46 & 100.0 & 100.0 & \\
\hline
\end{tabular}

\subsubsection{Level of education of respondents}

Table 4.3 shows the highest degree or level of school of participants. Of the respondents, $23(54.3 \%)$ of the participants were enrolled in Bachelor's degree.

\section{Table 4.3 Frequency and Percentage of Respondents by Level of Education}

\begin{tabular}{|ll|c|c|c|c|}
\hline & Frequency & Percent & Valid Percent & $\begin{array}{c}\text { Cumulative } \\
\text { Percent }\end{array}$ \\
\hline Valid & $\begin{array}{l}\text { Less than Bachelor's } \\
\text { degree }\end{array}$ & 14 & 30.4 & 30.4 & 30.4 \\
& 25 & 54.3 & 54.3 & 84.8 \\
Bachelor's degree & 7 & 15.2 & 15.2 & 100.0 \\
Graduate degree & 46 & 100.0 & 100.0 & \\
Total & &
\end{tabular}

\subsubsection{Marital status of respondents}

The distribution for the marital status of respondents is presented in Table 4.4. It shows that 28, which is $60.9 \%$ of single and 1 reprsenting $2.2 \%$ are divorced.

Table 4.4 Representing the Marital Status in Frequency and in

Percentage.

\begin{tabular}{|ll|c|c|c|c|}
\hline & & Frequency & Percent & Valid Percent & $\begin{array}{c}\text { Cumulative } \\
\text { Percent }\end{array}$ \\
\hline Valid & Single & 28 & 60.9 & 60.9 & 60.9 \\
& Married & 17 & 37.0 & 37.0 & 97.8 \\
\hline
\end{tabular}




\begin{tabular}{|l|c|c|c|c|}
\hline Divorced & 1 & 2.2 & 2.2 & 100.0 \\
Total & 46 & 100.0 & 100.0 & \\
\hline
\end{tabular}

\subsubsection{Nationally of respondents}

Table 4.5 shows the distributions for the number of participants responding to nationality. Of the respondents $(\mathrm{n}=46), 24(52.2)$ responded to Thai, and 22 (47.8) responded to Malaysian.

Table 4.5 Frequency and Percentage of Respondents by Nationality

\begin{tabular}{|ll|c|c|c|c|}
\hline & & Frequency & Percent & Valid Percent & $\begin{array}{c}\text { Cumulative } \\
\text { Percent }\end{array}$ \\
\hline Valid & Malaysian & 22 & 47.8 & 47.8 & 47.8 \\
& Thai & 24 & 52.2 & 52.2 & 100.0 \\
& Total & 46 & 100.0 & 100.0 & \\
\hline
\end{tabular}

\subsubsection{Working position}

The distribution of the respondents' working position is summarized in Table 4.6. Of the 46 respondents, $21(45.7 \%)$ responded that they were in skilled worker.

Table 4.6 Frequency and Percentage of Respondents by Working Position

\begin{tabular}{|ll|c|c|c|c|}
\hline & & Frequency & Percent & Valid Percent & $\begin{array}{c}\text { Cumulative } \\
\text { Percent }\end{array}$ \\
\hline Valid & Middle Management & 5 & 10.9 & 12.2 & 12.2 \\
& Junior Management & 7 & 15.2 & 17.1 & 29.3 \\
& Administrative Staff & 8 & 17.4 & 19.5 & 48.8 \\
& Skilled Worker & 21 & 45.7 & 51.2 & 100.0 \\
& Total & 41 & 89.1 & 100.0 & \\
Missing & 999 & 5 & 10.9 & & \\
Total & & 46 & 100.0 & & \\
\hline
\end{tabular}

\subsubsection{Year of working experiences of respondents}

The distribution of the year of working experiences is summarized in Table 4.7. Of the 46 respondents, 17 $(37.0 \%)$ responded that they were in 2-4 years, and 11 (23.9\%) Showed that they belong to 4-6 years of age.

Table 4.7 Frequency and Percentage of Respondents by Year of Working Experiences

\begin{tabular}{|ll|c|c|c|c|}
\hline & & Frequency & Percent & Valid Percent & $\begin{array}{c}\text { Cumulative } \\
\text { Percent }\end{array}$ \\
\hline Valid & Less than 2 & 12 & 26.1 & 26.7 & 26.7 \\
& $2-4$ & 17 & 37.0 & 37.8 & 64.4 \\
& $4-6$ & 11 & 23.9 & 24.4 & 88.9 \\
& More than 10 & 5 & 10.9 & 11.1 & 100.0 \\
& Total & 45 & 97.8 & 100.0 & \\
Missing & 999 & 1 & 2.2 & & \\
Total & & 46 & 100.0 & & \\
\hline
\end{tabular}




\subsection{Research Question Analysis}

The research questions were addressed using an independent t-test for these variables with 2 scales. All data analyses were performed at the 0.05 significance level. Degree of freedom (df) are also reported. The results of the analysis are presented in the Table 4.8 through 4.12 that follows. Moreover, in order to understand the significant difference between Malaysian and Thai employees in terms of conflict styles, the outcome is indicated in Table 4.13.

\subsubsection{Research Question One}

Research question one asked: Is there a statistically significant difference in preference of competing style between Malaysian and Thai employees?It was performed using the independent t-test to evaluate the variables with a 2 subscales. Table 4.8 shows the results of the analyses that were used to address the research question based on the country where the respondents are from.

The results of the analysis is shown in Table 4.8 indicated that there was a statistically significant difference among the Malaysian and Thai employees, the Levene F value is 3.177, and it is not statistically significant $(p=0.082)$. Thus, it is appropriate in this case to report the equal variances assumed version of t-test. The equal variance t-test result was statistically significant, $\mathrm{t}(44)=4.160, \mathrm{p}=$ 0.000 , two-tailed. Thus, using $\alpha=0.05$, two-tailed, as the criterion, the 2.659 point (not shown in the Table 4.8) difference in competing style between Malaysian and Thai employees was statistically significant. The effect size as indexed by $\tilde{\mathrm{n}}^{2}$ (eta squared), was 0.282 ; this is a large effect.

\section{Table 4.8}

\section{Determination of significance of use of competing style between Malaysian and Thai employees}

\begin{tabular}{|c|c|c|c|c|c|c|}
\hline & & $\mathrm{F}$ & Sig. & $\mathrm{t}$ & df & $\begin{array}{l}\text { Sig. (2- } \\
\text { tailed) }\end{array}$ \\
\hline Competing & $\begin{array}{l}\text { Equal variances } \\
\text { assumed }\end{array}$ & 3.177 & .082 & 4.160 & 44 & .000 \\
\hline & $\begin{array}{c}\text { Equal variances } \\
\text { not assumed }\end{array}$ & & & 4.088 & 35.859 & .000 \\
\hline
\end{tabular}

\subsection{Research Question Two}

Research question two asked: Is there a statistically significant difference in preference of collaborating style between Malaysian and Thai employees? The results of the analysis is shown in Table 4.9 indicated that there was a statistically significant difference among the Malaysian and Thai employees, the Levene $\mathrm{F}$ value is 0.563 , and it is not statistically significant $(\mathrm{p}=0.457)$. Thus, it is appropriate in this case to report the equal variances assumed version of t-test. The equal variance t-test result was statistically significant, $\mathrm{t}(44)=-2.140, \mathrm{p}=0.038$, two-tailed. Thus, using $\alpha=0.05$, two-tailed, as the criterion, the 0.996 point (not shown in the Table 4.9) difference in collaborating style between Malaysian and Thai employees was statistically significant. The effect size as indexed by $\tilde{n}^{2}$ (eta squared), was 0.094; this is a medium effect.

\section{Table 4.9}

Determination of significance of use of collaborating style between Malaysian and Thai employees.

\begin{tabular}{|c|c|c|c|c|c|c|}
\hline & & $\mathrm{F}$ & Sig. & $\mathrm{t}$ & df & $\begin{array}{l}\text { Sig. (2- } \\
\text { tailed) }\end{array}$ \\
\hline \multirow[t]{2}{*}{ Collaborating } & $\begin{array}{l}\text { Equal variances } \\
\text { assumed }\end{array}$ & \multirow[t]{2}{*}{.563} & \multirow[t]{2}{*}{.457} & -2.140 & 44 & .038 \\
\hline & $\begin{array}{l}\text { Equal variances } \\
\text { not assumed }\end{array}$ & & & -2.131 & 42.559 & .039 \\
\hline
\end{tabular}




\subsubsection{Research Question Three}

Research question two asked: Is there a statistically significant difference in preference of compromising style between Malaysian and Thai employees? The results of the analysis is shown in Table 4.10 indicated that there was a statistically significant difference among the Malaysian and Thai employees, the Levene $\mathrm{F}$ value is 1.247 , and it is not statistically significant $(\mathrm{p}=0.270)$. Thus, it is appropriate in this case to report the equal variances assumed version of t-test. The equal variance t-test result was statistically significant, $\mathrm{t}(44)=-2.671, \mathrm{p}=0.011$, two-tailed. Thus, using $\alpha=0.05$, two-tailed, as the criterion, the 1.345 point (not shown in the Table 4.10) difference in collaborating style between Malaysian and Thai employees was statistically significant. The effect size as indexed by $\tilde{\mathbf{n}}^{2}$ (eta squared), was 0.140; this is a large effect.

Table 4.10

Determination of significance of use of compromising style between Malaysian and Thai employees

\begin{tabular}{|cl|c|c|c|c|c|}
\hline & & $\mathrm{F}$ & $\mathrm{Sig}$. & $\mathrm{t}$ & $\mathrm{df}$ & $\begin{array}{c}\text { Sig. (2- } \\
\text { tailed) }\end{array}$ \\
\hline Compromising & $\begin{array}{l}\text { Equal variances } \\
\text { assumed } \\
\text { Equal variances } \\
\text { not assumed }\end{array}$ & 1.247 & .270 & -2.671 & 44 & .011 \\
\hline
\end{tabular}

\subsubsection{Research Question Four}

Research question two asked: Is there a statistically significant difference in preference of avoiding style between Malaysian and Thai employees? The results of the analysis is shown in Table 4.11 indicated that there was no statistically significant difference among the Malaysian and Thai employees, the Levene F value is large (18.657), and it is statistically significant $(\mathrm{p}=0.000)$. Thus, it is appropriate in this case to report the equal variances not assumed version of t-test. The equal variance t-test result was statistically significant, $\mathrm{t}(29)=-0.446, \mathrm{p}=0.659$, two-tailed. Thus, using $\alpha=0.05$, two-tailed, as the criterion, there was no statistically significant difference in avoiding style between Malaysian and Thai employees.

Table 4.11

Determination of significance of use of avoiding style between Malaysian and Thai employees

\begin{tabular}{|ll|c|c|c|c|c|}
\hline & & $\mathrm{F}$ & $\mathrm{Sig}$. & $\mathrm{t}$ & $\mathrm{df}$ & $\begin{array}{c}\text { Sig. (2- } \\
\text { tailed) }\end{array}$ \\
\hline Avoiding & $\begin{array}{l}\text { Equal variances } \\
\text { assumed } \\
\begin{array}{l}\text { Equal variances } \\
\text { not assumed }\end{array}\end{array}$ & 18.657 & .000 & -.459 & 44 & .649 \\
\hline
\end{tabular}

\subsubsection{Research Question Five}

Research question two asked: Is there a statistically significant difference in preference of accommodating style between Malaysian and Thai employees? The results of the analysis is shown in Table 4.12 indicated that there was no statistically significant difference among the Malaysian and Thai employees, the Levene $\mathrm{F}$ value is 6.504 , and it is statistically significant $(\mathrm{p}=0.014)$. Thus, it is appropriate in this case to report the equal variances not assumed version of t-test. The equal variance t-test result was statistically significant, $\mathrm{t}(39)=-0.149, \mathrm{p}=0.882$, two-tailed. Thus, using $\alpha=0.05$, two-tailed, as the criterion, there was no statistically significant difference in accommodating style between Malaysian and Thai employees.

Table 4.12 Determination of significance of use of accommodating style between Malaysian and Thai employees

\begin{tabular}{|l|l|l|l|l|l|}
\hline & & & & & Sig. (2- \\
& F & Sig. & $\mathrm{t}$ & df & tailed) \\
\hline
\end{tabular}




\begin{tabular}{|c|c|c|c|c|c|c|}
\hline Accommodating & $\begin{array}{l}\text { Equal variances } \\
\text { assumed } \\
\text { Equal variances } \\
\text { not assumed }\end{array}$ & 6.504 & .014 & $\begin{array}{l}-.146 \\
-.149\end{array}$ & $\begin{array}{c}44 \\
39.132\end{array}$ & $\begin{array}{l}.884 \\
.882\end{array}$ \\
\hline
\end{tabular}

Table 4.13 Analysis of cross-cultural difference in terms of conflict styles

\begin{tabular}{|l|l|l|l|c|c|}
\hline \multirow{2}{*}{ Competing } & Nationality & $\mathrm{N}$ & Mean & Std. Deviation & $\begin{array}{c}\text { Std. Error } \\
\text { Mean }\end{array}$ \\
\cline { 2 - 6 } & Malaysian & 22 & 4.91 & 2.580 & .550 \\
\cline { 2 - 6 } Collaborating & Thai & 24 & 2.25 & 1.700 & .347 \\
\cline { 2 - 6 } & Malaysian & 22 & 5.55 & 1.654 & .353 \\
\hline \multirow{2}{*}{ Compromising } & Mhai & 24 & 6.54 & 1.503 & .307 \\
\cline { 2 - 6 } & Malaysian & 22 & 6.36 & 1.465 & .312 \\
\hline \multirow{2}{*}{ Avoiding } & Malaysian & 22 & 7.09 & 2.328 & .388 \\
\cline { 2 - 6 } & Thai & 24 & 7.33 & 1.090 & .496 \\
\hline \multirow{2}{*}{ Accommodating } & Malaysian & 22 & 6.09 & 1.306 & .278 \\
\cline { 2 - 6 } & Thai & 24 & 6.17 & 2.078 & .424 \\
\hline
\end{tabular}

\section{Discussion}

The results of this study revealed that $24(52.2 \%)$ of the respondents were Thai, and $22(47.8 \%)$ were Malaysian. The $34(73.9 \%)$ of the respondents were under 24 and $9(19.6 \%)$ were between the ages of 25 and 34. There were $34(73.9 \%)$ females. In addition, $25(54.3 \%)$ of the respondents were graduated Bachelor's degree and 14 (30.4\%) were enrolled less than Bachelor's degree. Furthermore, 28 (60.9\%) of the respondents were single and $17(37.0 \%)$ were married. The majority of $21(45.7 \%)$ respondents reported that they were skilled worker. Of the 46 respondents, 17 (37.0\%) responded the year of working experiences between 2 and 4, and $5(10.9 \%)$ responded more than 10 years.

In sum, the result of independent t-test analysis showed a significant difference in preference for competing style, collaborating style, and compromising style. Thus, hypothesis 1, 2, and 3 were accepted. On the other hand, the result of t-test analysis showed no significant difference in preference for avoiding and accommodating styles. As a result, hypothesis 4 and 5 were rejected.

In hypothesis 1, this study found significant difference for a competing style of conflict between Malaysian and Thai employees. According to Malaysian's culture highly value collectivism with a score of 26 is collectivistic society as well as Thai culture focuses on collectivism with a score of 20 as shown in the Appendix C. Hofstede (1991) stated that people from individualistic society are self-centered and less likely the need of dependency whereas the people from collectivistic society are likely to lesser their own interests towards the group interests to work. This study revealed that Malaysian employees were more likely to select the competing style rather than Thai employees. It is possible that Malaysians are individualistic more Thais and causes them to favor competing style, although both of two countries are measured as collectivistic culture.

In hypothesis 2, this study found the significant difference for a collaborating style of conflict. Thai employees were more likely to select the collaborating style than Malaysian employees. This study revealed that Thai employees tend to be more collectivist than Malaysian employees. They are more likely to work with their counterparts to arrive at a mutually beneficial solution. However, it is possible that Thai people's collectivism causes them to favor collaborating style management with members but 
Malaysians may perceive their Thai counterparts as part of a competing group in which they may prefer not to collaborate.

In hypothesis 3, this study found the significant difference for a compromising style of conflict. According to interpersonal relationship is the most importance in terms of the value of Thai people, they maintain harmony more than other collectivistic countries. Thais were taught to end the conflicts by allowing the opposing party to gain benefits if the finding will not lose all of their benefits, and still leave some gains for them (Promsri, 2012). Thus, this study revealed that Thai employees were more likely to select the compromising style rather than Malaysian employees.

In hypothesis 4, this study found no significant difference for avoiding style of conflict between Malaysian and Thai employees. This was inconsistent with Hofstede (see Appendix C), who claimed that Thais were able to tolerate in the unclear, unstructured, and unknown situation. Thailand scores 64 on uncertainty avoidance indicating a preference for avoiding uncertainty, tend to be more accepting of risk. They are very focus on their set goalsand relationships or stay away from the issues over which the conflict isfrom the main point that generate disagreement taking place and from the persons. Whereas, Malaysia scores 36 on this dimension and thus has a low preference for avoiding uncertainty.

In hypothesis 5, this study found no significant difference for accommodating style of conflict between Malaysian and Thai employees. This was inconsistent with Hofstede, who claimed that Malaysians were more considered as a strong masculine compared to Thais (see Appendix C). At score 50 on masculine, Malaysia can be considered a masculine society - highly success oriented and driven. In masculine countries, people "live in order to work", conflicts are resolved by fighting them out. On the other hand, Thailand scores 34 on this dimension and thus is considered a feminine society. It is said to be a feminine society. Generally, the Thais people place priority on emotion and socializing, saving and giving faces than Malaysians. They think that conflict should be avoided in favor of harmony and that people cannot discuss conflicts without damaging relationships.

The issue of "Rubber City" in Malaysia and Thailand covers abroad range of issues. The cross-cultural differences in conflict styles between employees among two countries has been examined in very little of study especially in the context of rubber industry. This study demonstrated that differences exist between Malaysian and Thai employees in terms of their preferences for three out of five conflict styles that were identified (competing, collaborating and compromising). The findings from this study provide evidence of conflict styles management in rubber factory, as it seems to help explain how cultural differences relate to conflict styles management. Knowledge derived from the study could provide rubber companies an understanding of the five conflict modes and used to resolve conflict. There is a need for rubber companies to be aware of settling disagreement, resulting to the preparation for future MalaysianThai employees. Future research should identify and consider new samples.

\section{References:}

Asma, A. (1992). The influence of ethnic values on managerial practices in Malaysia. MalaysianManagement Review, 27 (1), 3-18

Census (2001), Population Distribution and Basic Demographic Characteristics: Report Population and Housing Census 2000, Malaysian Government Publications, Putra Jaya.

Consulting Psychologists Press (CPP). Thomas-Kilmann Conflict Mode Instrument. Palo Alto, California. Retrieved from:

http://www.foundationcoalition.org/publications/brochures/conflict.pdf

Fraenkel, J. R., \& Wallen, N. E. (2006). How to design and evaluate research in

education (6th ed.). New York: McGraw Hill.

Fieg, J.P. (1989), A Common Core: Thais and Americans, Intercultural Press, Yarmouth, ME.

Hocker, J.L., Wilmot, W.W. (1998), Interpersonal Conflict, 5th ed., Brown \& Benchmark, Madison, WI. 
Hofstede, G. (1991). Cultures and organizations software of the mind. London: McGraw-Hill.

Kinney.A. E (2001) e-how retrieved from:

http://www.ehow.com/about_6523993_cross_cultural-onflict_.html\#ixzz2U187ZptL

Komin, S. (1995). Cross-cultural management communication in Thailand. Paper presented at the SEAMEO's RELC Regional Seminar on Exploring Language, Culture, and Literature in Language Learning, SEAMEO Regional Language Center, Singapore, 17-19 April

Morris, M.W., Williams, K.Y., Leung, K., Larrick, R., Mendoza, M.T., Bhatnagar, D., Li, J., Kondo, M., Luo, J. and $\mathrm{Hu}$, J. (1998), "Conflict management style: accounting for cross-national differences", Journal of International Business Studies, Vol. 29 No. 4, pp. 729-47.

Oetzel, J.G., Ting-Toomey, S. (2003).Face concerns in interpersonal conflict: a cross-cultural empirical test of the face negotiation theory.Communication Research, 30( 6), 599-624.

Promsri, C. (2012). A comparison of preference for negotiation styles of Thais and Germans. Interdiscipnary Journal of Contemporary Research in Business, 4(4), 776-791.

Siira,K. Aula,P. (2010), "Organizational communication and Conflict Management Systems. A social Complexity Approach”. Nordicom Review, Vol 31 No.1, pp125-141.

The Foundation."Understanding the Conflict and Conflict Management". Retrieved from:

http://www.foundationcoalition.org/teams

Thomas, K. (1992), "Conflict and negotiation process inorganization", in Dunnette, M. and Houg, L. (Eds), Handbook of Industrial and Organizational Psychology, 2nd ed., Consulting Psychologist Press, Palo Alto, CA, pp. 145-52.

Thomas, K.W. and Kilmann, R.H. (1974), Thomas-Kilmann Conflict Mode Survey, Xicom, Tuxedo, NY.

Tinsley, C.H. (2001), "How negotiators get to yes: predicting the constellation of conflict management strategies used across cultures", Journal of Applied Psychology, Vol. 86 No. 4, pp. 583-93

Ting-Toomey, S. (1999), Communicating across Cultures, Guilford Press, New York, NY.

Ting-Toomey, S. (2003), "Managing intercultural conflict effectively", in Samovar, L.A. and Porter, R.E. (Eds), Intercultural Communication: A Reader, 10th ed., Wadsworth, Belmont, CA, pp. 373-84.

Top Glove (2012), Top Quality, Top efficiency: The world's Largest Rubber Glove Manufacture. Retrieved from http://www.topglove.com.my/index.php/about-us

Tourism Authority of Thailand (2007), Retrieved from: www.tourismthailand.org/about_thailand/ overview/facts.php (accessed 8 March 2007). 